\title{
Correlation of Work Motivation, Reward, and Punishment with Compliance Behavior in Using Personal Protective Equipment
}

\author{
Korelasi Faktor Motivasi Kerja, Reward, dan Punishment dengan Perilaku \\ Kepatuhan Penggunaan Alat Pelindung Diri
}

\author{
Alfi Wardina Faradisa, Tri Martiana \\ Department of Occupational Safety and Health, Faculty of Public Health Universitas Airlangga \\ Campus C Mulyorejo, Surabaya, East Java 60115
}

\begin{abstract}
Introduction: PT. X Surabaya is a company engaged in the field of construction services. Construction is an industrial sector which accounts for the highest accident rates in Indonesia. The high number of accidents in companies is a result of employee behaviors, one of which is related to the use of PPE. Based on Activator-Behavior-Consequence (ABC) model, factors that influence worker compliance behavior can be determined. From here, measures to strengthen or weaken the behavior can be proposed. This study aims to analyze the correlation between activator and consequence factors with compliance behavior in using PPE. Method: This study was an analytic observational study with a cross sectional design. This study used sample size by a total population of 32 construction workers at PT. X Surabaya. The variables studied were work motivation, reward, and punishment as independent variables, while the behavior of using PPE as the dependent variable in this study. Data were gathered by collecting company's secondary data, questionnaires, and observations by using critical behavior checklist instrument. The research analysis used the Spearman correlation statistical test. Results: The Spearman correlation statistical test showed that the relation between work motivation with compliance behavior in using PPE $(r=0.329)$, reward with compliance behavior in using PPE $(r=0.374)$, and punishment with compliance behavior in using PPE $(\mathrm{r}=0.263)$ was weak. Conclusion: Work motivation, reward, and punishment had a correlation with compliance behavior in using PPE, but these factors had a weak correlation. There may be other correlated factors in determining compliance behavior in using PPE.
\end{abstract}

Keywords: punishment, reward, work motivation

\begin{abstract}
ABSTRAK
Pendahuluan: PT. X Surabaya merupakan perusahaan yang bergerak di bidang jasa konstruksi. Konstruksi merupakan sektor industri yang menyumbang angka kecelakaan tertinggi di Indonesia. Tingginya angka kecelakaan di perusahaan ini akibat dari pekerja yang tidak berperilaku aman khususnya pada kepatuhan penggunaan APD. Berdasarkan model Activator-Behavior-Consequence (ABC), dapat diketahui faktor apa saja yang mempengaruhi perilaku kepatuhan pekerja yang selanjutnya akan di identifikasi bagaimana cara memperkuat atau memperlemah perilaku tersebut. Tujuan penelitian ini yaitu untuk menganalisis hubungan faktor activator dan consequence dengan perilaku kepatuhan penggunaan APD. Metode: Penelitian ini merupakan penelitian observasional analitik dengan rancang bangun penelitian cross sectional. Populasi dalam penelitian ini adalah seluruh pekerja konstruksi di PT. X Surabaya yang berjumlah 32 pekerja. Variabel independen dalam penelitian ini adalah motivasi kerja, reward, dan punishment, sedangkan variabel dependen dalam penelitian ini adalah perilaku kepatuhan penggunaan APD. Pengumpulan data dilakukan melalui pengumpulan data sekunder perusahaan, kuesioner, dan observasi menggunakan instrumen critical behavior checklist. Penelitian di analisis dengan menggunakan uji korelasi spearman. Hasil: Penelitian menunjukkan hubungan motivasi kerja dengan perilaku kepatuhan penggunaan APD memiliki kuat hubungan lemah ( $r=0,329)$, hubungan reward dengan perilaku kepatuhan APD memiliki kuat hubungan lemah ( $r=0,374)$, dan hubungan punishment dengan perilaku kepatuhan APD juga memiliki kuat hubungan lemah ( $r=0,263)$. Simpulan: Motivasi kerja, reward, dan punishment berhubungan dengan kepatuhan penggunaan APD, namun faktor-faktor tersebut memiliki korelasi yang lemah. Kemungkinan terdapat faktor lain yang berkorelasi dalam pembentukan perilaku kepatuhan penggunaan APD.
\end{abstract}

Kata kunci: motivasi kerja, punishment, reward

Corresponding Author:

Alfi Wardina Faradisa

Email: alfiwardina98@gmail.com

Telephone: +6287857622049

(C2021 IJOSH All right reserved. Open access under CC BY NC-SA license doi:10.20473/ijosh.v10i2.2021.208-217 Received July 09, 2020, received in revised form September 25, 2020, Accepted March 24, 2021, Published: August 2021 


\section{INTRODUCTION}

Construction is an industrial sector with a high risk of work accidents and takes many casualties (Ridley, 2006). Accidents in the construction sector are still a matter of work safety in Indonesia with this country ranking first contributing to the high number of work accidents (Ramdan and Handoko, 2016). Based on data from the Social Security Administrator (BPJS) for Manpower, throughout 2017 there were 1,877 incoming claims due to workplace accidents in the construction sector whose value was equivalent to Rp. 41.2 Billion.

According to the number of accidents that occurs frequently in the workplace, each construction company has made efforts to protect workers by applying controls according to the hierarchy of hazard control theory. One way to control work accidents that can be applied in the company is by implementing the use of Personal Protective Equipment (PPE). Using PPE is an effective alternative choice when a technical control cannot be done. However, many workers still do not comply with the use of PPE in the field because it is considered to interfere with work even though the company has provided PPE and implementing policies that require its use. According to Puspitasari and Nurcahyati (2018) there is a correlation between employee compliance in using PPE and accidents. Barizqi (2015) supports this statement, stating that $50.8 \%$ of respondents who were not compliant with the use of PPE experienced work accidents.

Efforts to reduce work accidents are done by increasing safety performance that can be achieved through reducing unsafe behavior. One of the efforts is Behavior Based Safety (Saodah, Silaban and Lubis, 2015). This is considered a method that has been proven capable of holding workers accountable for the safety of themselves and others at work. The statement is supported by the results of Handayani (2011) which showed a decrease in the frequency of unsafe behavior in workers when applying the Behavior Based Safety approach. This approach is effective if used as a process of improving work behavior that is safe for workers.

According to Geller (2001a), ABC model can be used in Behavior Based Safety approach. This consists of Activator-Behavior-Consequence. This model explains that behavior is influenced by activator factors as triggers of certain behaviors and the consequence factors that will determine whether the behavior will be done again in the future or not. Through the analysis of the ABC model, factors causing workers to behave insecently can be identified, and methods to change the behavior of these workers from unsafe behavior to safe behavior can be done (Affandhy and Nilamsari, 2017).

Workers who behave obediently in using PPE in the workplace can be driven by many factors, one of which is motivation. Work motivation is something that can provide encouragement and enthusiasm for work. Many factors can encourage the emergence of work motivation including appreciation from superiors and coworkers, physical facilities, policies or regulations, incentives in the form of money or non-money, and challenges (Dewantara, 2016). According to Dyah (2017), work motivation is one of the activator factors that can encourage workers to use PPE. Gunawan and Mudayana (2016) note that among workers, the behavior of using PPE and work motivation have a correlation. Workers with good work motivation use PPE better than those with poor motivation.

According to Putri and Martiana (2018), consequence is something that follows the behavior and influence, which allows the behavior to occur in the future. This means that consequence can strengthen or weaken the behavior to be carried out. Consequences that can improve behavior are reward, while punishment decreases behavior. Koencoro, Musadieq and Susilo (2013) explain that rewards can be in the form of bonuses / incentives, promotions, and benefits. Meanwhile, according to Putri and Martiana (2018), punishment can be in the form of sanctions from companies such as incentive cut.

This research was conducted at PT. X Surabaya. This company is engaged in construction services in Surabaya. The activities undertaken include the implementation of construction of civil structures such as the construction of waterways, highways, bridges, tunnels, and so on; implementation of building construction such as construction of warehouses and industry; and construction of mechanical and electrical installations such as installation of ventilation, heating, construction of water pipes, and so on. In addition, this company produces several types of products such as sandwich panel partitions, zincalume steel roof truss, ceiling or galvalume roof truss, and concrete fences. These activities have the risk of danger that can harm construction workers such as being hit by heavy objects, falling from a height, slipping, sprinkling fire from welding activities, and so forth.

According to the results of interviews with the OHS supervisor at PT. X Surabaya, unsafe behavior 
at work that can increase the risk of accidents is workers who are not compliant in using PPE. This disobedience still occurs even though the company has imposed fines for not complying with the use of PPE on workers and have carried out OHS promotion in the form of periodic socialization about the explanation of PPE functions, how to use PPE properly, and the impact of negligence for not using PPE. Therefore, workers need a stimulus with good work motivation such as praise and appreciation from superiors and coworkers or the provision of rewards in the form of both money and non-money. This research is used to identify factors that can influence behavior that can later be used as suggestions to companies to improve behavior of workers in using PPE and to minimize accidents.

\section{METHODS}

This study was a type of observational research because it was 'done by observing without giving certain treatment to research subjects, and the research was held in a certain period of time. Moreover, the appropriate research design used for this study was cross sectional design (Notoatmodjo, 2012). This research included analytical research with a quantitative approach. The research was conducted at the construction service company of PT. X Surabaya in May 2020 with 32 populations of workers. The entire population at PT. X Surabaya was used as the sample in this study and was determined by populated sampling techniques. The types of variables contained in this research were the independent and the dependent variables. The independent variables in the study were work motivation, reward, and punishment, while the dependent variable being studied was compliance behavior in using Personal Protective Equipment (PPE). Data sources used included company secondary data, while the primary data were obtained through validated questionnaires. The results of observations with the critical behavior checklist instrument were then analyzed using a statistical test, which was the Spearman correlation to express the level of correlation and the direction of the correlation between variables.

This research has been registered with an ethics certificate from the Health Research Ethics Committee (KEPK) of the Faculty of Public Health, Universitas Airlangga with ethical number No.15 / EA / KEPK / 2020.

\section{RESULTS}

\section{Frequency Distribution of Work Motivation}

The activator factor in this study was work motivation received by respondents at work. Table 1 explains that most of the respondents had good work motivation at work with a percentage of $56.3 \%$ with 18 workers. Meanwhile, $43.8 \%$ of other respondents had moderate work motivation with 14 workers.

\section{Frequency Distribution of Reward}

The consequence factor in this study was the reward received by the respondents at work. Table 2 explains that most of the respondents had the opinion that giving rewards was quite influential for workers to behave adherently to the use of PPE with a percentage of $65.6 \%$ or a total of 21 workers. Meanwhile, $34.4 \%$ or as many as 11 other respondents assessed that reward giving contributed to a good level of compliance for workers in using PPE.

Table 1. Frequency Distribution of Work Motivation Factors on Construction Workers at PT. X Surabaya in 2020

\begin{tabular}{ccc}
\hline Work Motivation & Frequency (n) & Percentage (\%) \\
\hline Good & 18 & 56.3 \\
Moderate & 14 & 43.8 \\
\hline Total & 32 & 100 \\
\hline
\end{tabular}

Table 2. Frequency Distribution of Reward Factors on Construction Workers at PT. X Surabaya in 2020

\begin{tabular}{ccc}
\hline Reward & Frequency $(\mathbf{n})$ & Percentage $\mathbf{( \% )}$ \\
\hline Good & 11 & 34.4 \\
Moderate & 21 & 65.6 \\
\hline Total & 32 & 100 \\
\hline
\end{tabular}

Table 3. Frequency Distribution of Punishment Factors on Construction Workers at PT. X Surabaya in 2020

\begin{tabular}{ccc}
\hline Punishment & Frequency (n) & Percentage (\%) \\
\hline Good & 14 & 43.8 \\
Moderate & 18 & 56.3 \\
\hline Total & 32 & 100 \\
\hline
\end{tabular}




\section{Frequency Distribution of Punishment}

The consequence factor in this study was the punishment received by respondents at work. Table 3 explains that most of the respondents thought that punishment was quite influential in making them behave according to the use of PPE with a percentage of $56.3 \%$ or a total of 18 workers. Meanwhile, $43.8 \%$ of other respondents thought that giving punishment to workers contributed to a good level of compliance in using PPE.

\section{Frequency Distribution of Compliance Behavior in Using PPE}

The frequency distribution of behavior factor for compliance with PPE was obtained through direct observation to workers at PT. X Surabaya. Table 4 explains that most of the respondents had a moderate level behavior regarding compliance with PPE usage $(43.8 \%)$. Meanwhile, a total of $25 \%$ of respondents behaved unfavorably regarding compliance with PPE usage. This is because some workers were still violating the use of PPE in the workplace.

Table 4. Frequency Distribution of Compliance Behavior in Using PPE on Construction Workers at PT. X Surabaya in 2020

\begin{tabular}{ccc}
\hline $\begin{array}{c}\text { C o m p l i a n c e } \\
\text { Behavior in Using } \\
\text { PPE }\end{array}$ & Frequency (n) & Percentage (\%) \\
\hline Good & 10 & \\
Moderate & 18 & 51.3 \\
\hline Poor & 14 & 100 \\
\hline Total & 32 & 100 \\
\hline
\end{tabular}

\section{Correlation Between Work Motivation and Compliance Behavior in Using PPE}

Based on the results of research at PT. X Surabaya, itis shown in Table 5 that most of the respondents, with good work motivation, also had good obedience behavior in using PPE, accounting for 8 workers $(25 \%)$. Moroever, from the acquisition of the Spearman correlation test statistical analysis, the value obtained was 0.329 as the correlation coefficient, which means that there was a weak correlation and positive direction between variables.

\section{Correlation Between Reward and Compliance in Using PPE}

Based on the results of research at PT. X Surabaya, it is shown in Table 6 that most of the workers who had a moderate opinion on the reward also had moderate and poor level of obedience in using PPE, with the similar number of workers between the two categories, accounting for 8 workers $(25 \%)$. Moreover, from the acquisition of the Spearman correlation test statistical analysis, the value obtained was 0.374 as the correlation coefficient, which means means that there was a weak correlation and positive direction between variables.

\section{Correlation Between Punishment and Compliance Behavior in Using PPE}

Based on the results of research at PT. X Surabaya, it shown in Table 7 that most of the respondents who had a moderate level of opinion about the giving of punishment also had a moderate

Table 5. The Correlation between Work Motivation and Compliance Behavior in Using PPE on Construction Workers at PT. X Surabaya in 2020

\begin{tabular}{|c|c|c|c|c|c|c|c|c|c|c|}
\hline \multirow{3}{*}{$\begin{array}{l}\mathbf{W} \quad \mathbf{0} \quad \mathbf{r} \quad \mathbf{k} \\
\text { Motivation }\end{array}$} & \multicolumn{6}{|c|}{ Compliance Behavior in Using PPE } & \multirow{2}{*}{\multicolumn{2}{|c|}{ Total }} & \multirow{3}{*}{$\begin{array}{l}\text { Correlation } \\
\text { Coefficient }\end{array}$} & \multirow{3}{*}{ P value } \\
\hline & \multicolumn{2}{|c|}{ Good } & \multicolumn{2}{|c|}{ Moderate } & \multicolumn{2}{|c|}{ Poor } & & & & \\
\hline & $\mathbf{n}$ & $\%$ & $\mathbf{n}$ & $\%$ & $\mathbf{n}$ & $\%$ & $\mathbf{N}$ & $\%$ & & \\
\hline Good & 8 & 25 & 7 & 21.9 & 3 & 9.4 & 18 & 100 & \multirow{2}{*}{0.329} & \multirow{2}{*}{0.066} \\
\hline Moderate & 2 & 6.3 & 7 & 21.9 & 5 & 15.6 & 14 & 100 & & \\
\hline
\end{tabular}

Table 6. The Correlation between Reward and Compliance Behavior in Using PPE on Construction Workers at PT. X Surabaya in 2020

\begin{tabular}{|c|c|c|c|c|c|c|c|c|c|c|}
\hline \multirow{3}{*}{ Reward } & \multicolumn{6}{|c|}{ Compliance Behavior in Using PPE } & \multirow{2}{*}{\multicolumn{2}{|c|}{ Total }} & \multirow{3}{*}{$\begin{array}{l}\text { Correlation } \\
\text { Coefficient }\end{array}$} & \multirow{3}{*}{$P$ value } \\
\hline & \multicolumn{2}{|c|}{ Good } & \multicolumn{2}{|c|}{ Moderate } & \multicolumn{2}{|c|}{ Poor } & & & & \\
\hline & n & $\%$ & n & $\%$ & n & $\%$ & $\mathbf{N}$ & $\%$ & & \\
\hline Good & 5 & 15.6 & 6 & 18.8 & 0 & 0 & 11 & 100 & \multirow{2}{*}{0.374} & \multirow{2}{*}{0.035} \\
\hline Moderate & 5 & 15.6 & 8 & 25 & 8 & 25 & 21 & 100 & & \\
\hline
\end{tabular}


Table 7. The Correlation between Punishment and Compliance Behavior in Using PPE on Construction Workers at PT. X Surabaya in 2020

\begin{tabular}{|c|c|c|c|c|c|c|c|c|c|c|}
\hline \multirow{3}{*}{ Punishment } & \multicolumn{6}{|c|}{ Compliance Behavior in Using PPE } & \multirow{2}{*}{\multicolumn{2}{|c|}{ Total }} & \multirow{3}{*}{$\begin{array}{l}\text { Correlation } \\
\text { Coefficient }\end{array}$} & \multirow{3}{*}{ P value } \\
\hline & \multicolumn{2}{|c|}{ Good } & \multicolumn{2}{|c|}{ Moderate } & \multicolumn{2}{|c|}{ Poor } & & & & \\
\hline & $\mathbf{n}$ & $\%$ & n & $\%$ & n & $\%$ & $\mathbf{N}$ & $\%$ & & \\
\hline Good & 6 & 18.8 & 6 & 18.8 & 2 & 6.3 & 14 & 100 & \multirow{2}{*}{0.263} & \multirow{2}{*}{0.146} \\
\hline Moderate & 4 & 12.5 & 8 & 25 & 6 & 18.8 & 18 & 100 & & \\
\hline
\end{tabular}

compliance behavior in using PPE, accounting for 8 workers (25\%). Morever, from the acquisition of the Spearman correlation test statistical analysis, the value obtained was 0.263 as the correlation coefficient, which means that there was a weak correlation and positive direction between variables.

\section{DISCUSSION}

\section{Work motivation}

An activator is an event that underlies or initiates every behavior done by someone before the behavior occurs. Activators can be natural whenthey are triggered by events that occur in the environment and can be planned when they are triggered by messages or warnings made by communicators (Mufida, 2017). The role of the activator does not always cause the behavior to occur, but it can also cause the behavior not to occur (Sirait and Paskarini, 2017).

One of the activator factors included in this research was work motivation. Work motivation is an encouragement for workers to meet their needs, such as security needs. According to the theory of needs developed by Maslow, motivation can also be used to classify human motives (Andjarwati, 2015). This shows that workers must have work motivation to determine what security needs are needed. One of the ways to fulfill the need for security in construction workers is through the PPE usage compliance.

The results of research on construction workers at PT. X Surabaya found that most of the research respondents had good work motivation, while others had a moderate level of work motivation. This can be caused by the desire and awareness of workers to behave safely while working. According to Sirait and Paskarini (2017), other factors that can support workers to behave safely are awareness and motivation from the surrounding environment. Gunawan and Mudayana (2016) is in line with this statement, suggesting that the most respondents had good motivation regarding PPE usage behavior $(52.9 \%)$. The results of another study conducted by Brito (2013) also stated that most workers had a good level of motivation in using PPE at work (76\%).

\section{Reward}

Reward is something that is expected from the behavior or positive feedback on the achievement given to workers (Munir, 2018). Rewards that are used properly can form feelings of confidence, selfesteem, self-control, a sense of optimism, and a sense of belonging for workers (Geller, 2001b). According to Muhith et al. (2018), which is in line with Sirait and Paskarini (2017), the provision of positive reinforcement in the form of rewards to workers is another way to form attitudes and safe behavior in the workplace, as well as a form of support that can be a stimulus for workers to comply with the use of PPE.

The results of research on construction workers at PT. X Surabaya show that the majority of research respondents believed that the rewards given by companies were quite influential. Munir's research (2018) findings are in line with that statement, which stated that most of the workers at PT. APRS had an opinion that reward was also quite influential in supporting compliance with PPE usage behavior with a percentage of $76.9 \%$. However, this is not in line with research conducted by Affandhy and Nilamsari (2017) and Fitriani and Nawawiwetu (2017), which stated that the majority of workers had never received a reward from the company, so reward had no effect on the compliance behavior of PPE use.

\section{Punishment}

Negative reinforcement in this study was the punishment received by individuals and groups. It is a form of the consequences of unexpected 
behavior. The aim is to strengthen or weaken the possibility of unexpected behavior repeated (Geller, 2001a). According to Putri and Martiana (2018), punishment is a form of negative consequences given to workers for reducing undesirable workers' behavior. Punishment can also be interpreted as a threat given to workers with the aim of improving the behavior of workers who violate regulations in the company (Mangkunegara, 2000). This is in line with the opinion of Sirait and Paskarini (2017) that punishment will be given to workers who have committed violations such as unsafe behavior committed by workers in the workplace.

The majority of construction workers at PT. $\mathrm{X}$ Surabaya believed that the punishment given by the company was quite influential. Munir's research (2018) is in line with that statement, stating that the majority of workers at PT. APRS believed that punishment was also quite influential in supporting compliance with PPE usage behavior with a percentage of $82.1 \%$.

\section{Compliance Behavior in Using PPE}

Behavior is any action or actions taken by someone, and it basically can be observed through attitudes and actions (Notoatmodjo, 2014). Behavior is an important factor that can cause accidents or reduce the number of accidents at work. Behavior that can reduce accidents is safe behavior at work, one of which is compliance behavior in using PPE. Tarwaka (2014) argues that the direct cause of an accident is an OHS requirement that is not implemented properly, for example the use of PPE.

In this study, the results were obtained through observation in the field by using the critical behavior checklist observation instrument sheet. The observation process was carried out twice in one work shift, i.e 10 am and 2 pm, which was carried out together with the OHS supervisor. According to the results of the frequency distribution obtained through observations in the field, most of the construction workers at PT. X Surabaya had good behavior, yet some had poor behavior. Candra's resesarch (2015) is also in accordance with this statement, which showed that most workers had compliant behavior (72.2\%). Affandhy and Nilamsari (2017) in their research also explained that the treatment of workers fell into the quite good category.

Based on interviews with PT. X Surabaya's OHS supervisors, the company has actively sought to promote OHS, especially in promoting good and correct PPE usage, PPE functions used by workers, and the impact caused by negligence in using PPE. However, even though the company has been active in promoting OHS, violations of the use of PPE still occur. Some construction workers said that they did not use PPE because it was uncomfortable using PPE too long, especially in the use of safety helmets. Some workers also thought that they felt normal and felt safe at work. This statement is supported by research of Brito's research (2013), stating that workers did not comply with the use of PPE because they felt protected even though they did not use PPE.

The results of nterviews with workers are also consistent with the results of observation stating that PPE which was often violated by workers was the use of safety helmet. This violation was more common at around $2 \mathrm{pm}$ to $3 \mathrm{pm}$ when the time was approaching the end of working hours. This shows that the concern of workers regarding the use of PPE must be increased to minimize the occurrence of work accidents. Cooper (2009) states that to reduce unsafe actions, the cultivation of safe behavior, especially in the use of PPE behavior, needs to be improved.

Behavior is one of the elements forming organizational culture whose end result is good performance so that it can form and run the wheels of the organization, in this case the company. Behavior in the organizational culture can be developed as part of a good OHS culture in the company to minimize the number of accidents at work (Kurniasih and Rachmadita, 2013).

\section{Correlation Between Work Motivation and Compliance Behavior in Using PPE}

According to the cross tabulation results obtained between work motivation and PPE usage compliance behavior, most of the workers who had good work motivation also had good behavior in using PPE as well. Brito's research (2013) supports this statement, stating that workers who were well motivated mostly had good behavior in using PPE (57.99\%). The results of Sirait and Paskarini (2017) research also stated the same finding that most workers with good motivation had good safe behavior.

The results of interviews with several construction workers of PT. X Surabaya shows that there were other factors which supported construction workers to behave in compliance with PPE, namely support from colleagues by reminding 
each other to behave safely, but this was not the case for all workers. In addition, rewards and punishments implemented by companies motivated workers even though their application was of low consistency. Affandhy and Nilamsari (2017) states compliance is caused by the triggers and consequences that exist in the workplace.

Statistical tests using the Spearman correlation explainthat work motivation and compliance behavior of workers in using PPE had a positive and unidirectional correlation. From a positive correlation, it can be seen that the higher the work motivation, the better the compliance behavior in using PPE on workers. The result obtained a value of 0.329 as the correlation coefficient,indicating that the correlation between work motivation and compliance behavior using PPE was weak. Fara, Kurniawan and Wahyuni (2017) support this statement by obtaining a correlation coefficient value of 0.358 in their study.

Dyah (2017) found a similar result with research conducted by Retnani and Ardyanto (2013) that motivation did not significantly correlate with PPE usage behavior. This is because although motivation in the use of PPE is an activator that plays a role in shaping the behavior of compliance with PPE use, it does not have enough influence to produce compliant behavior in using PPE (Putri, 2017).

According to Gunawan and Mudayana (2016), workers with good motivation in using PPE when working can protect themselves from diseases and accidents due to work. Meanwhile, workers with poor motivation have a 1.6 times higher chance of experiencing work accidents because workers do not have good safe behavior, especially in using PPE in the workplace.

\section{Correlation Between Reward and Compliance Behavior in Using PPE}

Based on the cross tabulation results obtained between reward and compliance behavior in using PPE, most workers who had a moderate opinion level about reward also had moderate and poor level of obedience towards compliance in using PPE at work. Munir's research (2018) also found a similar result, with a percentage of $43.3 \%$.

Statistical tests using the Spearman correlation explain that the reward and compliance behavior of workers in using PPE had a positive and unidirectional correlation. From the statistical results, a value of 0.374 was obtained as the correlation coefficient. It can be seen that the two variables, namely reward and compliance of workers who behaved obediently in using PPE had a weak correlation. Research conducted by Affandhy and Nilamsari (2017) and Retnani and Ardyanto (2013) also found a similar finding with this study, suggesting that giving rewards to workers did not have much effect on workers in behaving safely.

One of the causes of the weak correlation was the lack of clarity in giving rewards to workers. According to an interview with the OHS supervisor of PT. X Surabaya, the company did not have a standard policy regarding the presentation of rewards, so rewards were only known to workers verbally through OHS supervisors and project implementers. The reward given by the company was appreciation or praise from superiors and additional incentives in the form of transportation money for safe behavior at work.

Most workers also thought that they had not felt a clear and appropriate rewarding system for workers from the company. Affandhy and Nilamsari (2017) stating that there was no reward system for workers who had safe behavior. The awards given by the company were only in the form of praise but were not consistent, and not all workers received them.

Therefore, the PT K3 team of X Surabaya is advised to make and establish in advance a clear and written policy regarding the reward system that will be given to workers if they behave safely, especially regarding compliance behavior using PPE. The formulation of a reward system should be discussed openly in advance with workers so that the company knows the expectations of every worker who has a different perception in accepting the consequences given (Putri and Martiana, 2018).

\section{Correlation Between Punishment and Compliance Behavior in Using PPE}

The cross tabulation results obtained between punishment and compliance behavior in using PPE show that most workers with a moderate opinion level about the punishment also had a moderate compliance behavior in using PPE. Affandhy and Nilamsari (2017) also stated the same finding as that of this study, suggesting that $75 \%$ of workers behaved safely at a good level.

Statistical tests using the Spearman correlation explain that the punishment and compliance behavior of workers in using PPE had a positive and unidirectional correlation. From the statistical results, a value of 0.263 was obtained as the correlation 
coefficient. It can be seen that the two variables, namely punishment and compliance of workers who behaved obediently in using PPE, had a weak correlation. These results are supported by research by Retnani and Ardyanto (2013) which explained that punishment and workers' safe behavior had no meaningful relationship.

The correlation was weak because there was no written policy from the company regarding punishment. But workers had already known what consequences would be received if they did not comply with the use of PPE. OHS Supervisor of PT. X Surabaya said that the punishment given to workers who violated the use of PPE was quite influential, namely reprimand and fines in the form of money on each item of PPE that was violated. When workers committed serious violations such as being fined too often for not using PPE, the company had a policy to dismiss the workers. This was also confirmed by several construction workers of PT. $X$ Surabaya through interviews who explained that the fines imposed by the company affected them enough to behave safely. On the other hand, most of the other workers also stated that when they began to feel uncomfortable using PPE for a long time sometimes they chose to give up the PPE and that the sentence did not become something that workers had to avoid and fear. This was also due to weak supervision and consistency from the company.

The research of Putri and Martiana (2018) and Munir (2018) showed that a negative value and the relationship between variables was weak. Saraswati's research (2014) also supports this statement, suggesting there was no statistically significant relationship between punishment and safe behavior. This happens because punishment is not directly felt by all workers when they behave insecurely. The study of Muhith et al. (2018) and Munir (2018) also stated that the company did not implement a punishment system that was in line with procedures. Therefore, workers will only comply with the use of PPE if receiving a reprimand from the supervisor. However, workers tend to repeat not to use PPE when supervision is weak or there is no warning from supervisors.

Thus, it is better for the OHS team of PT. X Surabayato strengthen supervision so that workers maintain compliance behavior in the use of PPE and to establish a written policy regarding the punishment system so that its application is evenly distributed to all workers. Giving the consequences of both reward and punishment from the company is expected to maintain the compliance behavior in using PPE on construction workers at PT. X Surabaya. Geller (2001a) further states that consequence factors determine the behavior that is expected to be repeated or not in the future.

\section{CONCLUSION}

Compliance behavior in using PPE can be caused by the activator factor such as work motivation and the consequence factors such as reward and punishment. From research conducted at PT. X Surabaya, it can be seen that there was a weak correlation level between work motivation, reward, and punishment with compliance behavior in using PPE in the workplace. Thus, it can be concluded that activator and consequence factors were not necessarily the main factors in the formation of compliance behavior in using PPE on construction workers of PT. X Surabaya.

\section{ACKNOWLEDGEMENTS}

The authors would like to thank PT. X Surabaya as a place of research and also for their assistance in carrying out this research. The authors also thank parents for their support and sources of research funding until this scientific article is completed.

\section{REFERENCES}

Affandhy, L. R. and Nilamsari, N. (2017) 'Analisis Perilaku Aman Pada Tenaga Kerja Dengan Model ABC (Activator-Behavior-Consequence)', Journal of Industrial Hygiene and Occupational Health, 2(1), pp. 14-30.

Andjarwati, T. (2015) 'Motivasi dari Sudut Pandang Teori Hirarki Kebutuhan Maslow, Teori Dua Faktor Herzberg, Teori XY Mc Gregor, dan Teori Motivasi Prestasi Mc Clelland', Jurnal Ilmu Ekonomi Dan Manajemen, 1(1), pp. 45-54.

Barizqi, I. N. (2015) Hubungan Antara Kepatuhan Penggunaan APD Dengan Kejadian Kecelakaan Kerja Pada Pekerja Bangunan PT. Adhi Karya Tbk Proyek Rumah Sakit Telogorejo Semarang. Undergraduate Thesis. Semarang: Faculty of Sport Science, Universitas Negeri Semarang.

Brito, G. T. (2013) 'Analisis Aspek Pembentuk Budaya K3 Dengan Kepatuhan Penggunaan APD Pada Pekerja Produksi Resin Di Sidoarjo', The Indonesian Journal of Occupational Safety and Health, 4(2), pp. 134-143. 
Candra, A. (2015) 'Hubungan Faktor Pembentuk Perilaku Dengan Kepatuhan Penggunaan Alat Pelindung Telinga Pada Tenaga Kerja Di PLTD Ampenan', The Indonesian Journal of Occupational Safety and Health, 4(1), pp. 83-92.

Cooper, D. (2009) Behavioral Safety a Framework for Success. Franklin: B-Safe Management Solutions Inc.

Dewantara, B. S. (2016) Hubungan Motivasi Kerja dengan Kepatuhan Penggunan Alat Pelindung Diri (APD) Pada Perawat di Ruang Rawat Iinap Rumah Sakit Paru Jember. Undergraduate Thesis. Jember: Nursing Science, Universitas Jember.

Fara, R. A. Z., Kurniawan, B. and Wahyuni, I. (2017) 'Faktor-Faktor Yang Berhubungan Dengan Safe Behavior Pada Pekerja Rekanan Bagian Sipil Di PT. Indonesia Power Up Semarang', Jurnal Kesehatan Masyarakat (e-Journal), 5(5), pp. 318-326.

Fitriani, A. and Nawawiwetu, E. D. (2017) 'Hubungan Faktor Antesenden Dan Konsekuensi Dengan Safety Behaviour Di PT. X (Studi Pada Tenaga Kerja Di Industri Tekstil)', Journal Of Vocational Health Studies, 1(2), pp. 50-57.

Geller, E. S. (2001a) Behavior-Based-Safety in Industry: Realizing the Large-Scale Potential of Psychological to Promote Human Welfare. USA: Applied and Preventive Psychology.

Geller, E. S. (2001b) Working Safe: How To Help People Actively Care For Health and Safety. New York: Lewis Publisher.

Gunawan, I. and Mudayana, A. A. (2016) 'Hubungan Antara Pengetahuan, Sikap Dan Motivasi Dengan Perilaku Penggunaan Alat Pelindung Diri Pada Pekerja Bagian Produksi PT.Katingan Indah Utama, Kabupaten Kotawaringin Timur, Provinsi Kalimantan Tengah', Unnes Journal of Public Health, 5(4), pp. 336-347.

Handayani, Y. (2011) Pengaruh Penerapan Behavior Based Safety Terhadap Penurunan Jumlah Kecelakaan Kerja di PT. Denso Indonesia. Undergraduate Thesis. Jakarta: Faculty of Public Health, Universitas Pembangunan Nasional Veteran Jakarta.

Koencoro, G., Musadieq, M. and Susilo, H. (2013) 'Pengaruh Reward dan Punishment Terhadap Kinerja (Survei Pada Karyawan PT. INKA (Persero) Madiun)', Jurnal Administrasi Bisnis, 5(2), pp. 1-8.

Kurniasih, D. and Rachmadita, R. N. (2013) 'Pengukuran Budaya K3 Pada Tingkat Non
Manajerial Dengan Menggunakan Cooper'S Reciprocal Safety Culture Model Di PT. X', J@Ti Undip : Jurnal Teknik Industri, 8(2), pp. 83-88.

Mangkunegara, A. (2000) Manajemen Sumber Daya Manusia. Bandung: Rosada.

Mufida, M. R. (2017) Hubungan Faktor Activators dan Consequences Dengan Perilaku Kepatuhan Penerapan Standard Operating Procedure. Undergraduate Thesis. Surabaya: Faculty of Public Health, Universitas Airlangga.

Muhith, A. et al. (2018) 'Penggunaan Alat Pelindung Diri (APD) Masker Dengan Gangguan Saluran Pernapasan Pada Pekerja di PT. Bokormas Kota Mojokerto', Journal of Health Science (Jurnal Ilmiah Kesehatan), 3(1), pp. 20-33.

Munir, M. M. (2018) Hubungan Faktor Activator dan Consequence Dengan Perilaku Kepatuhan Penggunaan Alat Pelindung Diri Pada Pekerja di PT. ARPS. Undergraduate Thesis. Surabaya:Faculty of Public Health, Universitas Airlangga.

Notoatmodjo, S. (2012) Metode Penelitian Kesehatan. Jakarta: Rineka Cipta.

Notoatmodjo, S. (2014) Promosi Kesehatan Teori dan Aplikasi. Jakarta: Rineka Cipta.

Puspitasari, R. P. and Nurcahyati, D. D. (2018) 'Hubungan Antara Kepatuhan Penggunaan APD Dengan Kejadian Kecelakaan Kerja Karyawan Di PT. STI TBK. Cikupa Kabupaten Tangerang Tahun 2018', Jurnal STIKes Yatsi, 7(2), pp. 1-14.

Putri, K. D. S. (2017) 'Analisis Faktor yang Berhubungan dengan Kepatuhan Menggunakan Alat Pelindung Diri', The Indonesian Journal of Occupational Safety and Health, 6(3), pp. 311-320.

Putri, R. W. and Martiana, T. (2018) 'Hubungan Reward dan Punishment Dengan Perilaku Tenaga Kerja Dalam Menjalankan Program Stop', The Indonesian Journal of Occupational Safety and Health, 7(2), pp. 172-180.

Ramdan, I. M. and Handoko, H. N. (2016) 'Kecelakaan Kerja Pada Pekerja Konstruksi Informal Di Kelurahan "X" Kota Samarinda', Media Kesehatan Masyarakat Indonesia, 12(1), pp. 1-6.

Retnani, N. D. and Ardyanto, D. (2013) 'Analisis Pengaruh Activator Dan Consequence Terhadap Safe Behavior Pada Tenaga Kerja Di PT. Pupuk Kalimantan Timur Tahun 2013', The Indonesian Journal of Occupational Safety and Health, 2(2), pp. 119-129. 
Ridley, J. (2006) Kesehatan dan Keselamatan Kerja. Edited by L. Simarmata. Jakarta: Erlangga.

Saodah, S., Silaban, G. and Lubis, A. M. (2015) 'Penerapan Program Behavior Based Safety (BBS) dan Kecelakaan Kerja di PT Inalum Kuala Tanjung Tahun 2014', Jurnal USU Lingkungan dan Kesehatan Kerja, 4(1), pp. 27-30.

Saraswati, F. (2014) Analisis Activator dan Consequence Dengan Safe Behavior Penggunaan Alat Pelindung Diri Pada Tenaga Kerja Di PT. Du Pont Agricultural Products Indonesia Sidoarjo Tahun 2014. Undergraduate Thesis.
Surabaya: Faculty of Public Health, Universitas Airlangga.

Sirait, F. A. and Paskarini, I. (2017) 'Analisis Perilaku Aman Pada Pekerja Konstruksi Dengan Pendekatan Behavior-Based Safety (Studi Di Workshop Pt. X Jawa Barat)', The Indonesian Journal of Occupational Safety and Health, 5(1), pp. 91-100.

Tarwaka (2014) Keselamatan dan Kesehatan Kerja: Manajemen dan Implementasi K3 di Tempat Kerja. Surakarta: Harapan Press. 